\title{
スリット付き中空静置の水膜分雄性能*
}

\author{
坪 内 邦 良*1, 吉 田 正 平*1 \\ 佐藤武*2, 金子了市*2
}

\section{A Study of Separation of Water Film on a Hollow Blade with Suction Slits}

\author{
Kuniyoshi TSUBOUCHI, Shohei YOSHIDA, \\ Takeshi SATO and Ryouichi KANEKO
}

\begin{abstract}
The presence of water droplets in the low-pressure stage of a steam turbine leads to erosion of moving blade, especially of an advanced long blade, because of the larger blade tip speed and higher wetness. This paper describes the effect of the separation of water film through suction slits on the blade pressure surface. By assuming a linear velocity distribution with water film, the mass flow and film thickness of water moving on the blade pressure surface were calculated in order to determine the location of slits. Water flow separated through suction slits was measured in a wet steam tunnel under the same conditions of a low-pressure steam turbine. Droplet size and velocity were also measured for dispersed water droplets in the wake of the blade with and without suction slits by means of a fiber laser Doppler velocimeter (LDV). Test results indicated that the water separation coefficient is strongly affected by the location of slits and pressure difference between cascade inlet and drain separator. Finally, the flow rates of dispersed water droplets in the wake of the blade with suction slits are $30 \sim 40 \%$ lower than those in the wake of the blade without suction slits.
\end{abstract}

Key Words: Steam Turbine, Nozzle, Wake, Atomization, LDV, Flow Measurements, Wet Steam, Erosion

\section{1. 維}

湿り蒸気中で作動するタービンでは，静珼後流中に 発生する数 $10 \mu \mathrm{m}$ 以上の水滴が高速回転中の動翼に

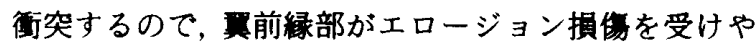
すい. 特に, 最新の艮賈では翼先端周速が $700 \mathrm{~m} / \mathrm{s} に$ 達するものもあり(1)，エロージョンに対して従来より もいっそう緟しい条件になっている。

このエロージョン損伤の原因となる粗大水滴は, 主 として静翼翼面上に形成される水膜流れが後緑端から 後流中に噴霧されてできるので，この水膜流れをでき るだけ除去することが望ましい。このため，静買を中 空構造とし，翼面にスリットを設けて水膜流れを内部 に吸引して分雖除去する方法が一部実機に採用されて いる。このスリット付き中空觧翼については，すでに モデルタービン実験(2) や翼列実験 ${ }^{(3)}$ が行われ，その水 膜分離特性が明らかになっているが，翼形形状や水膜 流れとスリットの関連が必ずしも明確になっていな is.

*平成 2 年 9 月 24 日 第 68 期全国大会陆演会において請演, 原稿受付 平成 3 年 6 月 19 日.

*1 正员，(侏)日立作所機械研究所（ $\mathbf{3} 317$ 日立市幸町3 $1-1)$

*2 正员，(怢)日立製作所 日立工場（8317 日立市幸町 3-1-1）
本研究は，このスリット付き中空静䔬による水膜分 離効果の把握を目的に，墨面上に捕集される水滴によ って生ずる水膜流の解析によってスリット位置を求め るとともに，その水膜分離効果を実験的に把握した。 さらに, LDVを用いてスリット付き静異の後流中に 発生する水滴を計測し，その流動特性を明らかにし た。

\section{2. 壾号}

\section{$C_{f}:$ 摩擦係数}

$C_{x}, C_{y}:$ 置の $x$ および $y$ 方向長さ（図 1 参照）

$G_{H}, G_{N}$ : 水滴の慣性パラメータ

$K n: ク ヌ ッ セ ン$ 数

$l:$ 翼面に浻う長さ

$\dot{m}_{f}:$ 水膜流量

$r:$ 水滴の半径

$R_{N}:$ 监前緑部半径（図 1 参照）

$t:$ 罣ピッチ

$u$ : 水膜速度

$U, V:$ 速度

$y:$ 湿り度

$\delta:$ 水膜厚さ

$\varepsilon$ : 水滴補集効率 


$$
\rho: \text { 密度 }
$$

$\xi, \eta:$ 罢面に添う座標軸

$\mu:$ 粘性係数

添字

$$
d: \text { 水滴 } L: \text { 水膜 } S: \text { 蒸気 }
$$

\section{3. 面上の水膜流れとスリット位嘈}

中空静置の累形形状に合せて最適なスリット位置を 求めるには，置面上に集積する水膜流れを解析する必 要がある. 実際のタービン段落内の流れは, 䙉雑な三 次元流れとなるのて，翼表面に形成される水膜流れも 極めて複雑な様相を示す(4). しかし，水膜は一般に蒸 気のせん断力や遠心力の影製を強く受けるので,ここ では静翼置面に捕集された水滴が蒸気のせん断力によ って薄い水膜となって一様に流れると仮定する，すな わち, 図 1 に示すように蒸気中に発生した微小水滴が 埲間流路に入ると, 大部分の水滴は蒸気流に乗って流 路内を通過するが，一部の水滴はその慣性力の効果で 静翼前縁部や腹面部に衡空して水膜流を形成する。こ の場合，その水膜厚さが極めて薄いので，運動量方程 式と連続の式は次式で表すことができる(5).
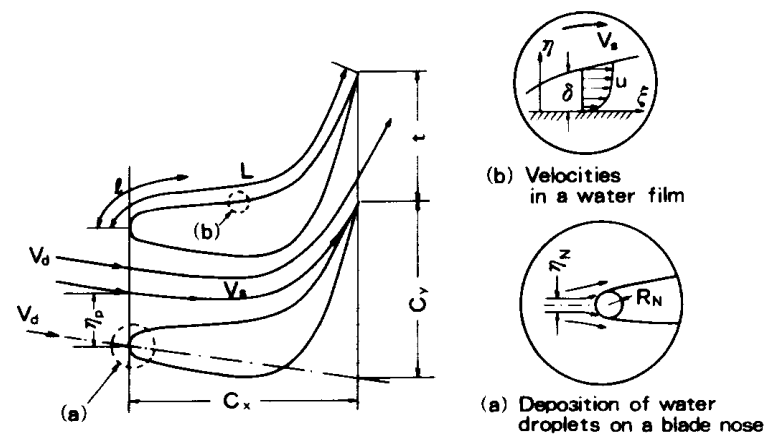

$$
\begin{aligned}
& -\left(\frac{\partial p}{\partial \xi}\right)+\mu_{L}\left(\frac{\partial^{2} u}{\partial \eta^{2}}\right)=0 \\
& \dot{m}_{f}=\rho_{L} \int_{0}^{s} u d \eta \cdots \cdots \cdots . . .
\end{aligned}
$$

境界条件は， $\eta=0: u=0$

$$
\eta=\delta:\left(\frac{\partial u}{\partial \eta}\right)=\tau_{s}+\tau_{n}
$$

ただし， $\tau_{s}:$ 蒸気のせん断力 $=C_{f} \cdot \frac{\rho_{s} V_{s}^{2}}{2}$

$$
\tau_{n}: \text { 水滴の围突力 }=\dot{m}_{f} \cdot V_{s} / l
$$

なお，摩㨲係数 $C_{f}$ は置面に沿う蒸気の速度変化を与 え，Truckenbrodt の境界合箖分方程式(6)を用いて運 動量厚さを求めることにより計算した。

式（1）の圧力項は棲分すると水膜厚さ $\delta$ の乗の オーダとなるので,この項を無視すると, 式 (1)〜 (4) から水膜厚さ $\delta$ は次式で近似できる.

$$
\delta \fallingdotseq\left[\frac{2 \mu_{L}}{\rho_{L}} \cdot \frac{\dot{m}_{f}}{\tau_{s}+\frac{\dot{m}_{f}}{l} \cdot V_{s}}\right]
$$

ここで, $\dot{m}_{f}$ は単位買長当たり面に捕集される水滴 量なので,この水滴捕集効率を $\varepsilon$ とすると,

$$
\dot{m}_{f}=\varepsilon \cdot \rho_{s} \cdot \frac{y}{1-y} \cdot V_{s} \cdot t
$$

水滴捕集効率 $\varepsilon$ ध Gyarmathy $の$ 理論(5) に基づいて次 式を用いた。すすなわち, 図 1 に示すように水滴が買腹 面に衝突する領域を $\eta_{P}$ ，翼前緑部に衝突する領域を $\eta_{N}$ とすると

$$
\begin{aligned}
& \varepsilon=\left(\eta_{P}+\eta_{N}\right) / t \\
& \eta_{P}=2 C_{y} \cdot\left(G_{H}+e^{-C_{H}}-1\right) / G_{H}^{2} \\
& \eta_{N}=2 R_{N} \cdot\left(G_{N}+e^{-G_{N}}-1\right) / G_{N}^{2}
\end{aligned}
$$

ここで, $G_{H}, G_{N}$ は水滴の慣性パラメータを表し，

$$
G_{H} \equiv \frac{\left(9 \mu_{S} / 2 \rho_{L}\right)}{(1+2.53 K n)} \cdot \frac{C_{y}}{\left(V_{s} \cdot r^{2}\right)}
$$

図1面面における水滴捕集と水膜流れ

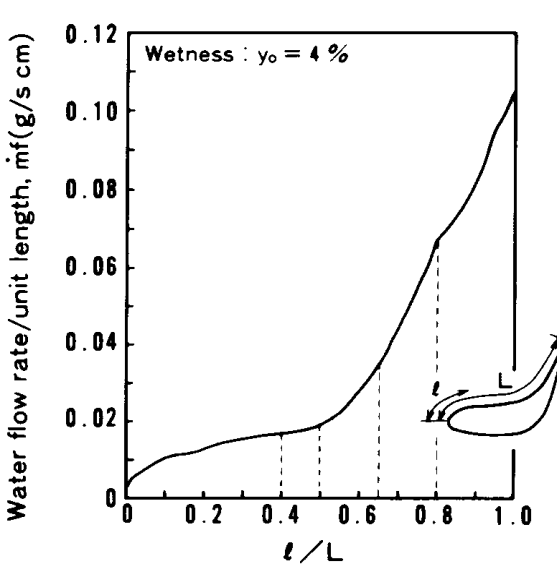

（a）単位畏当たりの水膜流吾

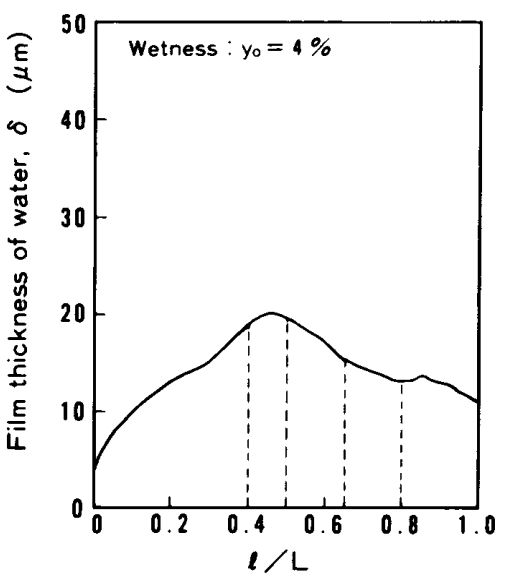

（b）兲面の水膜の层さ

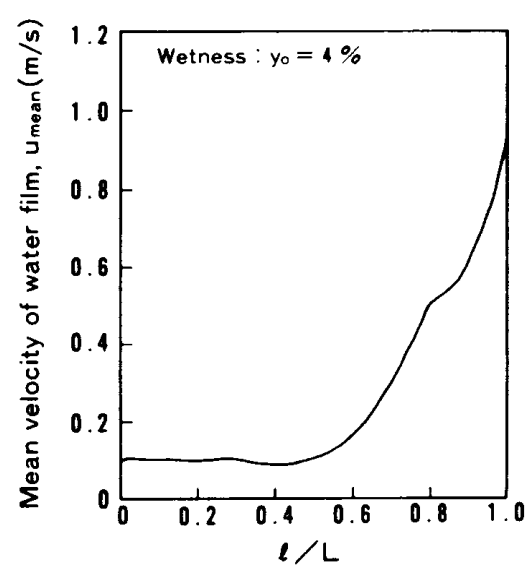

（c）宣表の水莫の速度

図 2 買腹面上の水膜流れの計算結果 


$$
G_{N} \equiv \frac{\left(9 \mu_{S} / 2 \rho_{L}\right)}{(1+2.53 K n)} \cdot \frac{2.5 R_{N}}{\left(V_{d} \cdot r^{2}\right)}
$$

図 2 ( a ) 〜 ( c )に, 低圧タービン最終段の典型的な 静具の腹側壁面上の解析結果の一例を示す，冥先端部 から水滴が衡突するにしたがって水膜原さおよび流量 が徐々に增加するが，流れが転向する面面中央部から 下流側で，水膜流量が增加するものの，水膜の速度も 急増するので水膜席さは減少する傾向を示す．面面の スリット位置については, Deich らのモデルタービン 実験結果など(2) を参考に以下の蜆点から選定した。す なわち, 面面の水膜厚さが最も厚くなる面面位圈 $l / L$ $=0.4$ および 0.5, 榙造上の制約からスリット位置とし て最も下流側の $l / L=0.8$ さらに $l / L=0.8$ のスリット 位固の流量のほほ $1 / 2$ となるスリット位置 $l / L=0.65$ を選んだ。

\section{4. 实駼装}

スリット付き中空觧異の水膜分崔特性および零後流 中の水滴の流動特性を把暒するため, 二次元翼列風洞 による湿り蒸気実験を実施した，図 3 に実験萃置の系 統を，図 4 にモデル翼形形状を，表 1 に実験条件を示

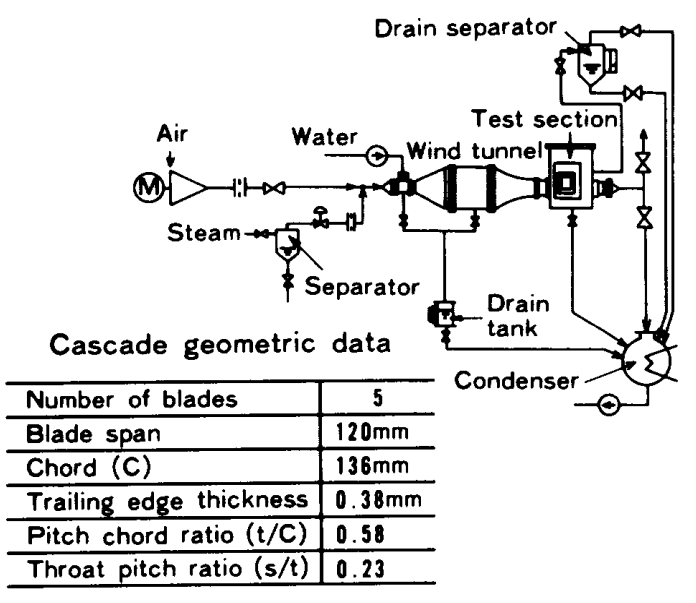

図 3 湿り蒸気・湿り空気睓列風洞実耠装置系統図

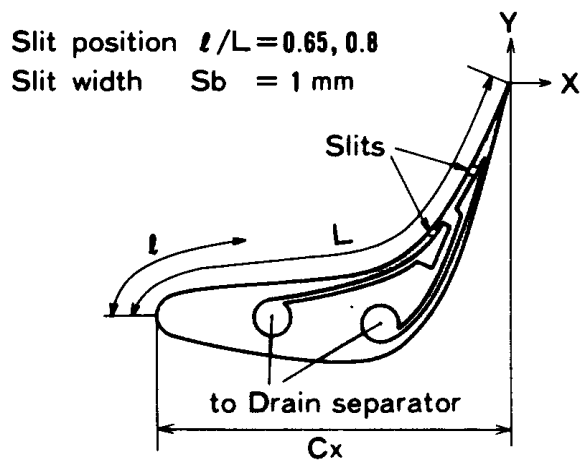

図 4 供試䨘形モデル
す．本装置では過熱蒸気または圧縮空気中に加圧水を 傄称して湿り蒸気または湿り空気を作りここの流体を

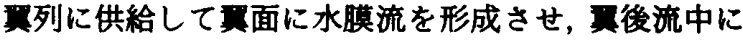

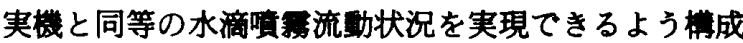
してある，剆定部の罢列は実機の $2 / 5$ モデルで，その 中央部にスリット付き静罢を配置した。 また,スリッ 卜付き静䆝の中空部を復水器に接続してあるので, バ ルブを開閉することにより水膜の吸込みの有無を調節 することが可能である。

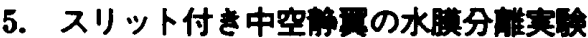

$5 \cdot 1$ 实験方法 実験では，所定の湿り度を有す る湿り蒸気を罢列に供給して軍の腹面上に水膜流を形 成させた後，測定を開始した。スリット部に吸い込ま れた水膜の量は, ドレンセパレータで随伴蒸気を分離 させた後, タンクレベルで測定した。なお，貢列入口の 湿り度は，各部の圧力, 温度, 噴霛水量, 乾き蒸気量を 測定して, 熱バランスから求めた。

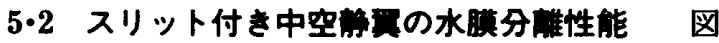
5 に罢列に流入する蒸気の入口湿り度 $y_{0}$ を変えて行 った各スリットの水膜分離実験結果を示す。水膜分離 奻率 $\phi$ は, 次式で定義した。

$\phi \equiv \frac{(\text { スリットからの水膜分離量) }}{(\text { 筫間流路当たりの流入水滴量) }}$

表 1 水膜分噰実検の蒸気条件

\begin{tabular}{|l|c|c|c|}
\hline & Unit & Cascade inlet & Cascade exit \\
\hline Pressure & $\mathrm{MPa}$ & 0.029 & 0.022 \\
\hline Temperature & ${ }^{\circ} \mathrm{C}$ & 67.9 & 60.6 \\
\hline Wetness & $\%$ & 4.0 & 5.3 \\
\hline Velocity & $\mathrm{m} / \mathrm{s}$ & 56.5 & 329.0 \\
\hline Flow angle & deg. & 0.0 & 13.25 \\
\hline
\end{tabular}

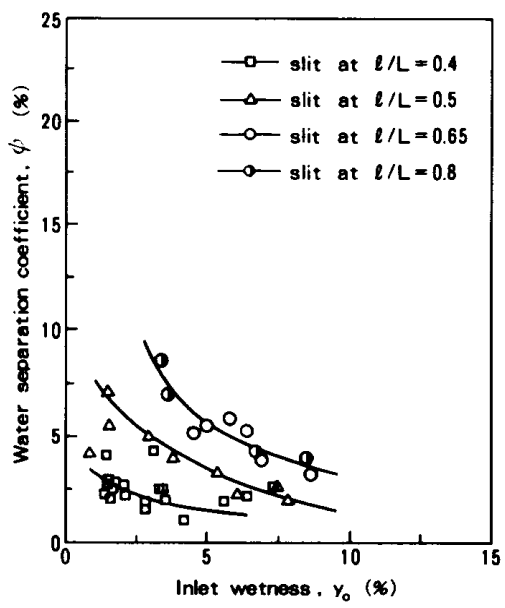

図 5 スリット位置と水膜分離奻率 
各スリットともに, 湿り度 $y_{0}$ の小さい領域で分離効 率が高く，y が増加すると奻率 $\phi$ が減少する。これは， 望間流路内では脚張仕事により湿り度が変化するが， その変化割合は入口湿り度が大きくなるほど, 小さく なることによると考えられる.また，l/Lが大きくなる と, 前述の解析結果から予测されるように水膜分踓効 率 $\phi$ も大きく改善できる.

図 6 は, 翼面にスリットを 2 本設けた場合の水膜分 離効率の実験結果を示す.上流側のスリット以降の水 膜が下流側のスリットで分踓できるので, 水膜分離効 率は同等となると予想されたが, $l / L=0.65$ と 0.8 の分 雖性能のほうが高くなった。この結果より, 各スリッ トの水膜吸込負荷配分が等しくなるようスリット位望 を選ぶのが妥当であると言える。

図 7 は, $l / L=0.65$ および 0.8 のリット付き中空静 置について，水膜分離効率 $\phi$ に対するスリット部の差 圧 $\Delta P$ の影饘を示す。ここで，スリット部の差压 $\Delta P$ として（買列入口部圧カードレンタンク内部圧力）を

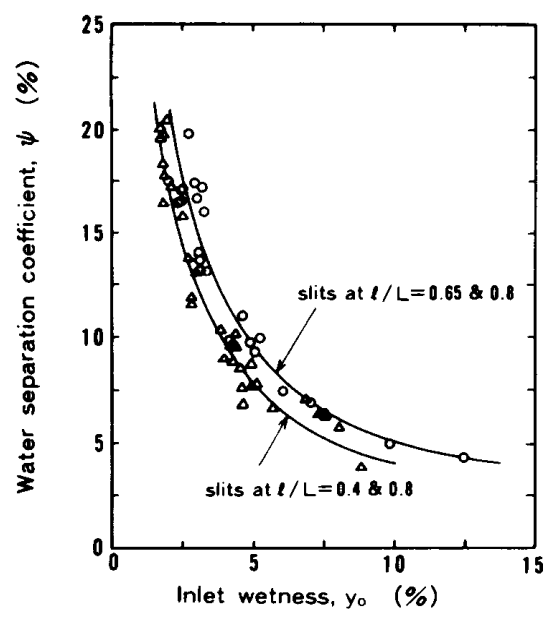

図 6 スリット 2 本の場合の水膜分離効率比較

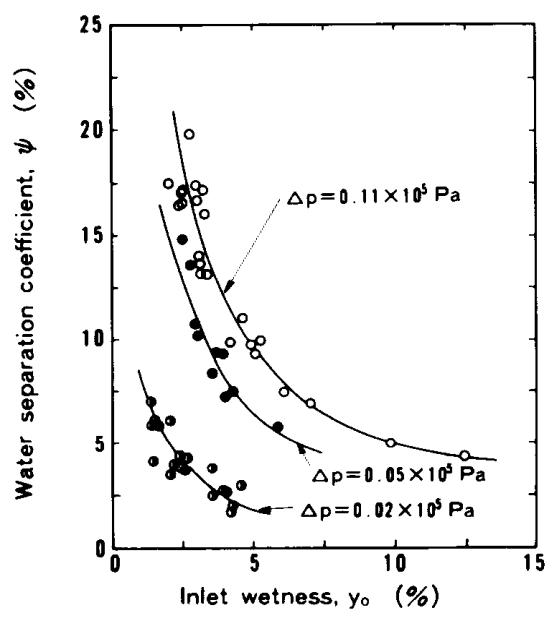

図 7 水膜分崔効率に対するスリット部差圧の影签
採用した。差圧 $\Delta P$ を大きくすると，水膜分離効率 $\phi$ も大きくなることがわかる。なお， $\Delta P=0.11 \times 10^{5} \mathrm{~Pa}$ は, スリット前後の圧力比がほほ臨界圧力比になり， スリット部の流れがチョークする状態である.

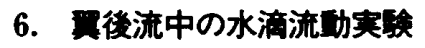

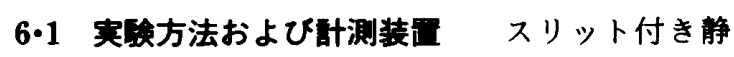
害の後流中の水滴の流動特性を把暒するため, 二次元 罢列実験を実施した。実験装置および供試置形は水膜 分離実験に用いたものと同じものである，ただし，本 実験では計測上の問題から作動流体として蒸気の代わ りに湿り空気を用いた。すなわち, 図 3 に示すように 圧縮機で加圧した空気中に加圧水を噴雾することによ り所定の湿り度を有する湿り空気を買列に供給し，翼 面に水膜流を形成させるとともに，買後流中に実機と 同様の水滴噴荷二相流を実現させた。実験は, 表 2 の 実臨条件で $l / L=0.65$ および 0.8 のスリット付き静罩 の後流中に光ファイバ LDV のプローブを挿入し, 水 滴の速度，粒径および数密度を測定した。なお、レイノ ルズ数およびウェーバ数は翼弦長 $C$, 翼出口部の主流 速度 $U_{\infty}$ および水滴速度 $V_{d}$, 最大水滴径 $d_{\mathrm{pmax}}$, 表面 張力 $\sigma$ とすると,

$$
\begin{aligned}
& R e=\rho_{s} U_{\infty} C / \mu_{s} \\
& W e=\rho_{s}\left(U_{\infty}-V_{d}\right)^{2} d_{\mathrm{pmax}} / \sigma
\end{aligned}
$$

図 8 に本実験の測定に用いた光ファイバ LDVの光 学系を, 図 9 に信号処理系の構成を示す. 光学系はア ルゴンガスレーザを光源とし，その 2 色 4 光束のレー ザビームを光ファイバを通してプローブ部に尊き，収

\section{表 2 覃後流中の水滴の流娌条件}

\begin{tabular}{|l|c|c|}
\hline & wet steam & wet air \\
\hline Inlet pressure & $0.029 \mathrm{MPa}$ & $0.11 \mathrm{MPa}$ \\
\hline Exit pressure & $0.022 \mathrm{MPa}$ & $0.10 \mathrm{MPa}$ \\
\hline Inlet wetness & $1.0 \%$ & $0.45 \%$ \\
\hline Exit velocity, $\mathrm{U}_{\infty}$ & $329.0 \mathrm{~m} / \mathrm{s}$ & $120.7 \mathrm{~m} / \mathrm{s}$ \\
\hline Reynolds number & $1.4 \times 10^{6}$ & $1.1 \times 10^{6}$ \\
\hline Weber number & 84 & 91 \\
\hline
\end{tabular}

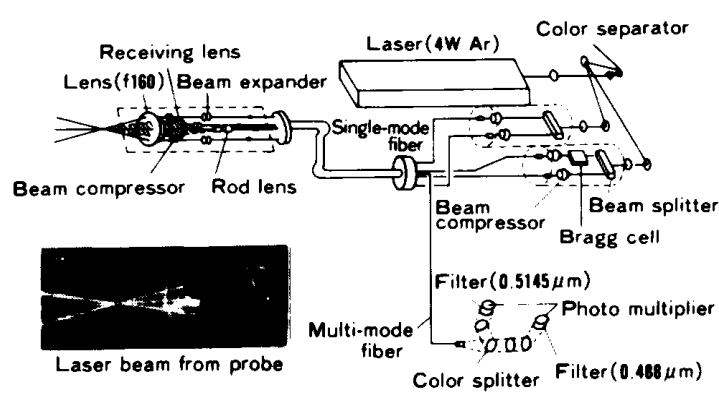

図84ビームファイバLDV システムの光学系 
束レンスの焦点位国に 4 ビームを交差させ測定体箖を 構成する．測定は測定体䅡を通過した個々の水滴から の後方散乱光のパルス強度と，2 方向のドップラー信 号を信号処理して水滴の粒径と速度べクトルを求め る.なお，詳細は文献 $(7)$ ( 8 )を参照願いたい。

\section{2 スリット付き解受後流中の水滴誉功 静異}

面面に形成した水膜を吸い込んだと（スリット前後 の圧力比 $\left.P_{s} / P_{0}=0.55\right)$ と, 吸い込まないときの置後流 中の平均水滴速度 $V$ と平均水滴径 $d_{p}$ の測定結果を 図 10,11 に示す.なお, 水滴速度 $V$ は空気主流の速度 $U_{\infty}$ て無次元化し，図 10,11 の $X / C_{x}$ は測定位置で軸 方向測定位置 $X$ を置幅 $C_{x}$ で無次元化して示した。図 10 およびび図 11 より翼後流中心部に比较的速度が遅 く, 大きな水商が集中するとともに, ピッチ方向に離 れるにしたがって速度が速く, 粒径の小さな水滴が存 在していることがわかる.これらの水滴は, 軸方向に 離れるにしたがって加速され， $X / C_{x}=0.39$ では後流 拡散の影整でほほ一様な速度および粒径となってい る.図 10，11では，水膜の吸込みの有無による実験結 果を比較しているが, 水滴速度および水滴径に大きな 差異は生じていない。これは 5 章の水膜分離結果から わかるように，水膜の吸込みによる分離効果が $10 \%$ 前

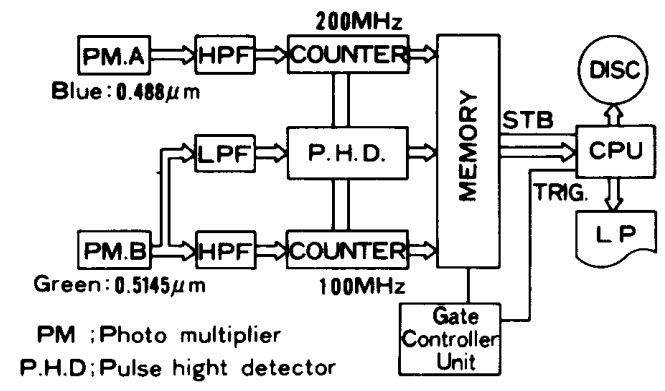

図 9 信号処理システム

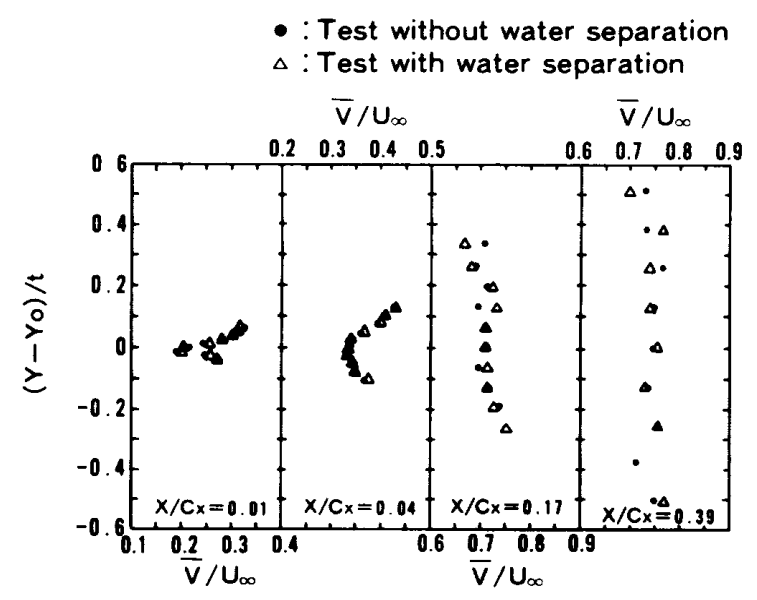

図 10 置後流中の平均水滴速度
後と少なく, 票後緑端近傍の水滴啫害現象を大きく変 えるほど影䇺を与えていないことを意味する。

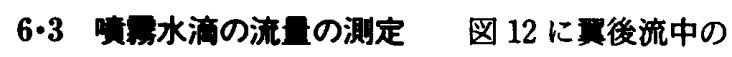
水滴径の願度分布を測定した結果の一例を示す. 図 12 より明かなように，水膜の吸込みの有無によって粒径 分布の形状に大きな変化は認められないものの, その 頻度の絶対值が異なることになる，すなわち，スリッ トから面上の水膜を吸い込むことにより，買後流中 に再噴䈥される水滴の流量を低減できることが本図か らも明らかである。この効果を定量的に把握するため， 測定された粒径分布を箖分し，各測定位置における噴 霧水滴流量の比較を行った。図 13 に水膜の吸込みの有 無による噴䨓水滴流量の軸方向変化を示す.図 13 の各 図の横軸はピッチ方向の測定位置を，縦軸は測定した 噴雾水滴の流量を示したもので，各測定点の湘定流量 $G_{s}(Y), G_{0}(Y)$ を水膜を吸い込まない場合の最大の測 定水滴流量 $G_{0 \max }$ で無次元化して示した. 圧力比は $P_{s} / P_{0}=0.55$ とほほ臨界圧力比に近い条件である. 図 13 中 (a)の測定位置 $X / C_{x}=0.01$ では, 翼後流中心近 傍に水滴流れが集中し, 翼間流路の中央部では水滴は ほとんど流れない。 また， $\left(Y-Y_{0}\right) / t<-0.025$ の静翼 背側には実験点がないが，これは静翼の背側では水膜

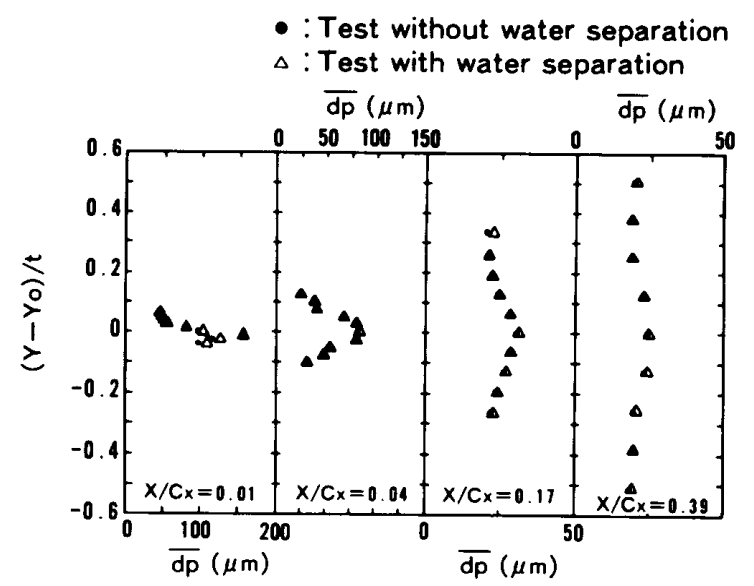

図 11 買後流中の平均水滴径
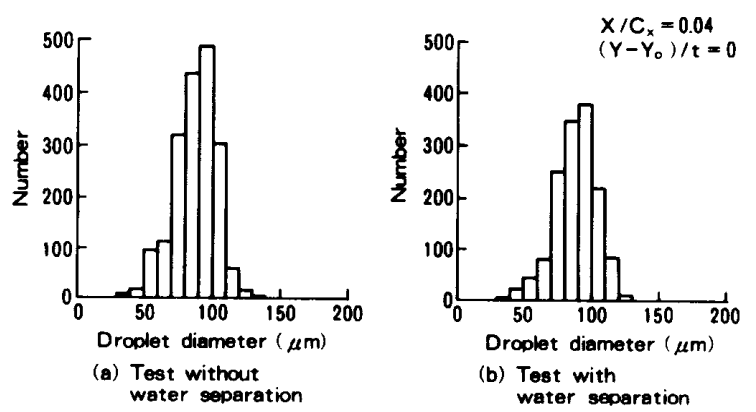

図 12 water separation 


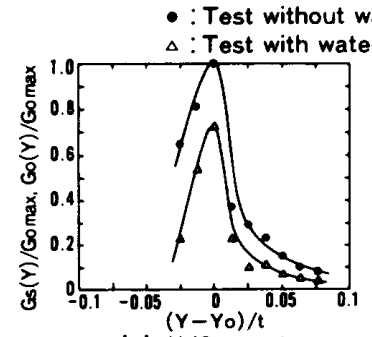

(a) $X / C_{x}=0.01$

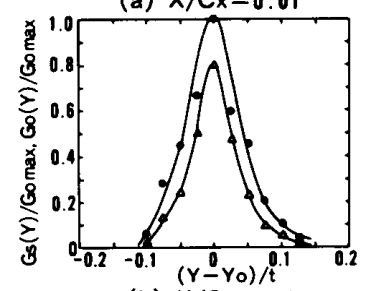

(b) $X / C_{x}=0.04$

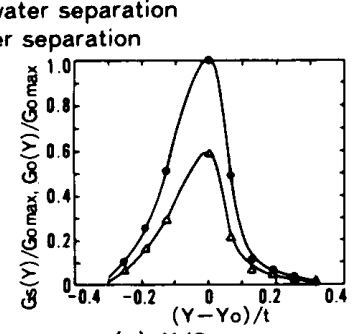

(c) $x / C x=0.17$

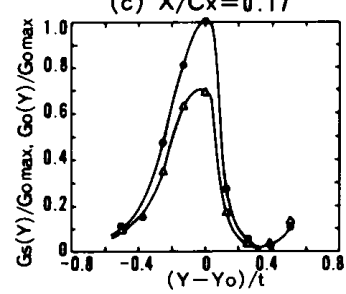

(d) $\mathrm{X} / \mathrm{Cx}_{\mathrm{x}}=0.39$
図 13 悬後流中の局所水滴流量分布

流れがほとんど形成されず水滴が噴雾される頻度が極 めて少なくなったことに起因している.

一方, 図 $13(\mathrm{~d})$ の测定位置 $X / C_{x}=0.39$ では, ほほ 翼間流路全体に噴霧された水滴か流れている。図 13 よ り，いずれの位置においても水膜を吸い込むと，後緑 端から噴霧される水滴流量がかなり減少する結果を示 している.すなわち，翼後緑端から噴第する水滴は，粒 径や速度は変化しないものの, その噴出頻度が水膜の 吸込みによって大きく低減てきる。このため，下流側 を回転する動墨へ衙突する水滴の数が少なくなり，工 ロージョン発生をかなり抑制することが可能となる.

水膜分離の実駼結果ても述べたが，スリット前後の 差圧を変えると，水膜の分離効率が大きく変化する. このような条件における望後流中の水滴流量を測定し た結果を図 14 に示す。図 14 は横軸にスリット圧力比 を，縦軸には水膜を吸い込んだ場合の噴霧水滴の流量 と水膜を吸い込まなかった場合の噴雾水滴の流量との 比を示す。なお，本図の流量はピッチ方向に積分した 水滴流量を示す. 図 14 中の印は測定位置 $X / C_{x}=$ 0.04 で圧力比を変化させた場合の測定結果である。圧 力比を小さくする，すなわちスリット差圧を大きくす ると水膜の吸込量が多くなり，その結果，噴霧水滴の 流量が滅少することがわかる。しかし，圧力比が 0.5 0.6 以下になると, 噴霧水滴の流量はそれ以上変 化しない.これは, 圧力比が 0.53 て臨界圧力比となり, 䠦界圧力比以下にしてもスリット部でチョークするの で，水膜を吸い込む流量が一定となるためである，図 14 には, スリット前後の圧力比 $P_{s} / P_{0}=0.55$ において 軸方向の各位置で測定した結果（○印）も示している

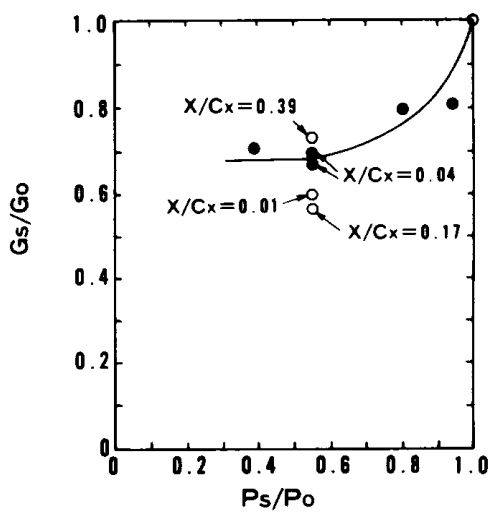

図 14 基後流中の全水滴流量に対する スリット部差圧の影彎

が、測定流量にばらつきがあるものの, スリット付き 觧覃によって噴霧水滴の流量を $30 \sim 40 \%$ 削減できる ことが明らかである。

\section{7. 桔}

蒸気タービンのエロージョン防止策の一つとしての スリット付き中空觧咀について，その水膜分離性能と 翼面スリット位置との関係および分離性能に対するス

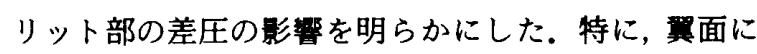
2 本以上のスリットを設ける場合，それぞれのスリッ 卜部の水膜吸込量をほほ等しくなるよう設定するこ と，また少なくともスリット部がチョーク流れになる よう吸込圧力を調整すると分離効率が向上する。

一方, 基後流中の水滴挙動を光ファイバ LDV シス テムにより測定した結果をまとめると，スリット付き 静墨の置後流中の水滴噴霧流動現象は, 水膜の吸込み 有無の影䇺を受けないものの，買後流中に噴霧する水 滴の流量は圧力比を小さくするほど減少し，水滴流量 が水膜を吸い込まない場合に対して 20〜40\%減少す ろ.

\section{文献}

（1）坪内・ほか 4 名，日立評論，70-2 (1988), 53.

(2) Deich, N. E., ほか3名, Teploenergetika, 15-11 (1968), 104.

(3) Ryley, D. J., ほか 1 名, PIME, 182-3H (1967-68), 94.

(4) Moore, M. J., ほか1名, PIME, 184-3G (1969-70), 45.

(5) Gyarmathy, G., Dissertation ETH, Zurich, Juris-Verlag, (1962).

(6) Trockenbrodt, E., NACA TM, 1379 (1955).

（7）坪内・ほか 3 名，機論，55-512，B (1989)，1022

(8) Tsubouchi, K., ほか 3 名, JSME Int. J., Ser. II, 32-2 (1990),511. 